\title{
Sağlık İnanç Modeli' ne Dayalı Olarak Öğretmenler ve Okul Yöneticilerinin Salgına Yönelik Bireysel Hazırlık Algılarının İncelenmesi
}

\author{
DOI: $10.26466 /$ opus.868717 \\ * \\ Öz

\author{
Ahmet Kaya * - Banu Moçoşoğlu** - Halil İbrahim Sevim *** \\ E-Posta: akaya574@hotmail.com \\ ORCID: 0000-0001-8899-9178 \\ ** Öğretmen, MEB/Şehit Fatih Mehmethan İlkokulu, İstanbul/Türkiye \\ E-Posta: banumocosoglu@gmail.com \\ ORCID: 0000-0001-7416-396X \\ *** Müdür Yardımcısı, MEB/Yaylakonak İlkokulu, Adıyaman/Türkiye \\ E-Posta: halil.ibrahim.sevim@gmail.com \\ ORCID: 0000-0001-5419-1090
} \\ * Doç. Dr., Kahramanmaraş Sütçü İmam Üniversitesi/Eğitim Fakültesi, Kahramanmaraş/Türkiye
}

\begin{abstract}
COVID-19 salgininin yaşanması sebebiyle salgina yönelik olarak bireysel tedbirlerin ve hazırlkları önemi toplum gündeminde daha fazla yer almaya başlamıştır. Bu araştırmada da toplumun en önemli kesitlerinden biri olan eğitim sektöründe yer alan öğretmenlerin ve okul yöneticilerinin mevcut salgznalsalgınlara yönelik olarak bireysel hazırlık algılarmm Sağllk Inanç Modeli'ne göre hangi düzeyde olduğunun tespiti ve çeşitli değişkenlere göre bu düzeyin farkllık gösterip göstermediğinin belirlenmesi amaçlanmıştır. Araştırmanm evrenini Kahramanmaraş ve Şanlıurfa illeri merkez ilçeleri ile Adryaman ili merkezinde bulunan devlet okullar oluşturmaktadır. Araştırmanm örneklemini ise seçkisiz örneklem yöntemi ile seçilen 403 öğretmen ve okul yöneticisi oluşturmaktadır. Analizler ilgili katıllmclardan derlenen 403 veri seti üzerinde gerçekleştirilmiştir. Araştırmada betimsel tarama modelinden faydalanılmıştır. Araştırma kapsamında bağımsı değişken olarak kullanilan yaş, cinsiyet, öğrenim durumu, medeni durum, çocuk sahibi olup olmama durumu, aylık gelir düzeyi ve unvan bilgileri ile anlaml farklllk olup olmadığının tespiti parametrik ve non-parametrik testler ile gerçekleştirilmiştir. Buna göre araştırmada betimleyici istatistik yöntemler, bağımsı örneklemler t-Testi, Tek Yönlü Varyans Analizi (ANOVA), Kruskal-Wallis H testi kullanılmıştır. ANOVA testindeki anlamlı farkllık kaynağının tespiti için Post-Hoc çoklu karşılaştırma testlerinden Scheffe; Kruskal-Wallis H testindeki anlaml farkllik kaynağının tespiti için de Bonferroni çoklu karşlaştırma testinden yararlanılmıştır. Araştırma sonuçlarma göre; öğretmenlerin ve okul yöneticilerinin salgina yönelik bireysel hazırlk algı düzeyleri yaş, cinsiyet, öğrenim durumu, medeni durum ve aylk gelir değişkenleri bakımından anlamlı bir fark tespit edilmişken; çocuk sayısı ve unvan değişkenleri bakımından ise anlaml bir fark tespit edilmemiştir. Ayrıca öğretmenlerin ve okul yöneticilerinin salgına yönelik bireysel hazırlık algı düzeylerinin ölçek genelinde "Katıliyorum" seviyesinde olması nedeniyle yüksek düzeyde olduğu tespit edilmiştir.
\end{abstract}

Anahtar Kelimeler: Salgın, Bireysel Hazırlık, Sağllk İnanç Modeli, Öğretmenler, Okul Yöneticileri 


\title{
Examining Teachers' and School Administrators' Perceptions of Individual Readiness for the Epidemic Based on the Health Belief Model
}

\begin{abstract}
Because of the COVID-19, the importance of individual measures and preparations for the epidemic has started to be more on the public agenda. In this study, it was aimed to determine the level of individual readiness perceptions of teachers and school administrators according to the Health Belief Model in the education sector, which is one of the most important sections of the society and to determine whether this level differs according to various variables. The population of the research consists of the public schools in the Central Districts of Kahramanmaraş and Şanluurfa Provinces and in the Central District of Adiyaman Province. The sample of the study consists of 403 teachers and school administrators selected by the random sampling method. Analyses were carried out on 403 data sets compiled from relevant participants. The descriptive survey model was used in the research. Parametric and non-parametric tests were used to determine whether there was a significant difference with age, gender, educational status, marital status, whether or not having children, monthly income level and title information used as independent variables within the scope of the study. Accordingly, descriptive statistical methods, unpaired $t$-test, One Way Analysis of Variance ANOVA test and Kruskal-Wallis $H$ test were used in the study. Scheffe, one of the Post-Hoc multiple comparison tests was used for the determination of the source of significant difference in the ANOVA test and Bonferroni multiple comparison test was used to determine the source of significant difference in the Kruskal-Wallis $H$ test. According to the results of the research; While a significant difference was determined in terms of the individual preparedness perception levels of teachers and school administrators for the epidemic in terms of age, gender, educational status, marital status and monthly income variables; There was no significant difference in terms of number of children and title variables. In addition, it was determined that the perception levels of individual readiness for the epidemic of teachers and school administrators were at a high level due to the "I agree" level throughout the questionnaire.
\end{abstract}

Keywords: Outbreak, Individual Preparation, Health Belief Model, Teachers, School Administrators 


\section{Giriş}

"Sağlık İnanç Modeli"ni oluşturan kavramlardan ilki olan sağlık, yalnızca bireyin hasta olmama hali değil; fiziksel, sosyal ve mental yönden tam anlamda iyi olma halidir (WHO, 1946). Birden fazla tanımı bulunan sağlık kavramı, bireylerin fiziksel durumlarıyla birlikte ruhsal ve sosyal olarak da iyi durumda olmaları anlamına da gelir. Başlangıçta sağlık kavramı ile sadece fiziksel durum göz önünde bulundurulurken 19. yy.'dan itibaren ruh hali durumu da sağlık kavramının kapsamında kullanılmaya başlanmıştır. Yaşam biçimi insanların bilinçli, kontrollü kararlarının sonucudur ve sağlık açısından duruma bakılacak olursa ancak olumlu sağlık davranışlarının sergilenmesiyle birlikte bu durum kişide sağlıklı yaşam biçimi şekline dönüşmektedir. Sağlıklı yaşam biçimi için bireylerin inanarak ve isteyerek bu davranışları sergilemesi gerekliliği vardır (WHO, 1984). "Sağlık İnanç Modeli"ni oluşturan kavramlardan ikincisi olan inanç ise; kişilerin kendi içlerindeki herhangi bir konuya dair tanımlamalarından kaynaklanan, sürekliliği olan duyguları ve kişisel ilkeleri ifade eden bir başka kavramdır. Davranış ise bu inançların dışa vurumu anlamına gelmektedir (Peker ve Zengin, 2019).

Kişilerin sağlıkları, sağlıkla ilgili inançlarından ve davranışlarından önemli düzeyde etkilenir. Sağlık inancı; kişinin sağlıklı olma haline veya hastalık haline yönelik düşünce ve davranışlarının ifadesidir. Kişilerin bu inançları neticesinde sağlıklarına yönelik davranışları şekillenmekte ve sonuç itibariyle olumlu ya da olumsuz olarak sağlıklarını etkilemektedir (Ünsal, 2017). Her ne kadar bireylerin sağllğı genetik ve bireysel faktörlerden etkilense de bireylerin sağlıklarına yönelik bilgi durumları ve davranışları çok önemlidir (Gözüm ve Çapık, 2014). Bireyler hasta olduklarında doğal olarak sağlıklarını kazanmak için bir takım davranışta bulunurlar. Fakat çağdaş halk sağlığı felsefesine göre hastalık halinden ziyade, önemli olan kişinin hasta olmadan önce sağlığını koruması ve geliştirmesidir (Öztek, Üner ve Eren 2012).

Son yıllarda hastalıkların önlenmesi ve erken teşhisi için uygulanan programlara insanların çok ilgi göstermemesinin sebebini araştırmak ve aynı zamanda insanların sağlıklarına yönelik davranışlarını açıklamak üzere "Sağlık İnanç Modeli" geliştirilmiştir (Rosenstock, 1974). Sağlık İnanç Modeli, son 50 yıldır sağlık davranışını açıklama noktasında en kapsamlı 
modeldir. 1950'li yıllarda Amerika'da halk sağlığı araştırmacıları, halka sağlık alanında verilen sağlık eğitiminin daha verimli olması için psikososyal bir model geliştirmeyi planlamışlardır. Araştırmacılar yaş, cinsiyet, sosyoekonomik düzey, etnik köken gibi demografik özelliklerin kişilerin sağlıklarını koruma davranışlarında etkili olduğunu; fakat sağlık hizmetleri ücretsiz sunulsa da düşük sosyoekonomik düzeyli insanların sağlık hizmetini daha az kullandıklarını fark etmişlerdir. Bu tablonun nedenlerini açılamak için Rosenstock (1966)"Sağlık İnanç Modeli” ni ilk kez kullanılabilir olarak geliştirmiştir (Gözüm, 2004; Gözüm ve Çapık, 2014). Sağlık İnançModeli'ni 1950'li yıllarda bazı sosyal psikologlar, hasta olmadan önce önleyici tedbir amacıyla geliştirmişlerdir (Hochbaum, 1958).

Sağlık İnanç Modeli'ne göre sağlık davranışı; bireylerin demografik özellikleri, bilgi ve tutumlarından etkilenir. Bireyin davranışları, hastalığa yönelik ciddiyeti algılama ve duyarlılık gösterme davranışları ile hastalık tehdidini azaltmak için harekete geçilmesinin getireceği yararı algılama davranışlarından etkilenir. Bu model, bireyde davranış değişikliğinin oluşabilmesi için bireyin inançlarının değişmesi gerektiğini vurgular (Özvarış, 2011). Öz (2004) ise; Sağlık İnanç Modeli'ne göre bireylerin sağlık davranışlarının onların inanç, değer ve tutumlarından etkilendiğini belirtir. Aynı zamanda birey için engeller oluşturan bu inanç ve tutumlar tespit edilirse bireye verilecek olan sağlık eğitiminin veya hastalandığında kendisine uygulanacak olan tedavi yöntemlerinin daha uygun olarak belirlenebileceğine dikkat çeker.

Sağlık İnanç Modeli'ne göre, bireylerin sağlıklarıyla ilgili davranışlarının faydalarını ya da zararlarını iyi anlaması, onları sağlıklarını koruma anlaminda harekete geçirecektir (Champion ve Skinner, 2008). "Sağlık İnanç Modeli", bireylerin sosyo-demografik özellikleri ile bilgi ve tutumlarına göre sağlık davranışı sergilediklerini savunmaktadır. Bu model kişinin göstereceği davranışları, hastalığa yönelik ciddiyeti algılaması ve hastalığa yönelik göstereceği duyarlılığa karşın önceden önlem alınmasının getireceği yararı algılamasıyla bağdaştırmaktadır (Champion, 1994; HSGM, 2020). Sağlık İnanç Modeli'ne göre bireylerde sağlık davranışının oluşması için bireylerin hastalığı önemsemeleri ve ciddiye almaları gerekmektedir. Aynı zamanda taramaların yarar ve engellerinin farkında olmaları, taramayla alakalı olumlu farkındalık yarataneğitim, medya gibi alanlar ile sağlık kontrollerini hatırlatan uyarılar almaları ve çevresinden birinin hastalanması 
veya bir başkasından bilgi alması gibi bireye olumlu katkıda bulunan uyarıclların olması gerekmektedir (Ersin ve Bahar, 2012).

"Sağlık İnanç Modeli" bireylerin sağlık davranışlarının açıklanması, sağlıklı olma halinin sürdürülmesi ve önleyici-koruyucu sağlık davranışlarıyla ile ilgili araştırmalarda kullanılmaktadır (Ersin ve Bahar, 2012). Sağlık İnanç Modeli'ne göre kişisel inançlar bireylerin sağlıkla ilgili davranışlarında belirleyici roldedir. Bu model ayrıca, sağlık görevlilerinin, doktorların, hasta davranışlarına yönelik olumlu sağlık davranışlarının önündeki engelleri tespit etmeye olanak sağlayarak hastaya daha fazla yardımcı olma imkanı sunmaktadır (Glanz vd.,2002). Sağlık İnançModeli, bireylerin sağlıklarını koruma ve geliştirmeleri için sergiledikleri davranışları incelemekle beraber muhtemel bir hastalık halinde iyileşme sürecinde önemli rol oynayan motivasyon ve engellerin neler olduğunu tespit etmeye çalışmaktadır. Bu modele göre; bireylerin sağlık davranışının ardında inanç ve değerleri yer almaktadır. Bu açıdan olumsuz inanç ve değerlerin tespit edilerek müdahale edilebileceği ve tedavi sürecinde olumlu motivasyonun sağlanabileceği düşünülmektedir (Gözüm ve Çapık, 2014). Sağlığı korumaya yönelik davranışları açıklamaya çalışan "Sağlık İnançModeli", hasta davranışlarıyla beraber sağlık davranışlarının sergilenmesinde belirleyici olan etmenleri de tespit etmeye çalışır (Kahraman vd.,2015). Sağlık İnanç Modeli'ne göre, bireylerin sağlık davranışlarına fayda sağlayan veya sağlık davranışlarını engelleyen etkenlerin fark edilmesi ve harekete geçilmesi önemlidir. Çünkü kişinin hastalığa yönelik inançları, sağlığına yönelik tutumlarına etkide bulunur (Gözüm ve Çapık, 2014).

Sağlık İnanç Modeli, "duyarlılık, önemseme, yarar ve engel, ciddiyet" gibi kavramları temel alan bir yaklaşımdan oluşmaktadır (Rosenstock, 1974). Sağlık İnanç Modeli, bireylerin mevcut sağlıklarını korumaları ve oluşabilecek hastalıkların önlenmesi için tedbir yöntemlerini ele alan bir modeldir. Bu modele göre bireyleri önleyici tedbirler noktasında harekete geçiren etmenler; bireylerin "algıladıkları duyarlılık, algıladıkları ciddiyet, algiladıkları yarar ve algilanan engellerdir". Bu etmenler bireyin hastalık durumuyla ilgili olumlu-olumsuz düşüncelerini de etkilemektedir. Bu etmenlerden algilanan yarar ile algılanan engeller arasındaki fark fazla olursa bireylerin olumlu sağlık davranışları sergilemelerinin azaldığı görülürken yarar, duyarlılık ve ciddiyet algiları, engel algısına göre yüksek düzeyde 
olması durumunda ise bireylerin olumlu sağlık davranışları sergilemelerinin arttı̆̆1 görülmektedir. (Champion, 2008).

Gözüm ve Aydın (2004), Sağlık İnanç Modeli'nde bireylerin önleyici sağlık davranışları üzerinde etkili olan "algılanan duyarlılık, önemsemeciddiyet, yarar ve engel" algilarına, Becker ve Rosenstock' un 1988 yılında "sağlık motivasyonu ve güven" kavramını da eklediğini belirtmişlerdir. Ayrıca Sağlık İnanç Modeli'nde inanç ve davranışlarla ilgili olan kavramları altı başlık altında şu şekilde sıralamışlardır:

- Duyarlılık algısı; bireyin sağlık durumunda var olabilecek tehlikeyi algilaması olarak tanımlanmaktadır.

- Ciddiyet/önemseme algısı; bireyin kendisi için tehlikeli ve sonuçlarının zararlı olacağı durumları önceden algılaması anlamına gelmektedir.

- Yarar algısı; bireyinkoruyucu sağlık davranışlarının oluşmasında olumlu yönleri algılamasıdır.

- Engel algısı; bireyin koruyucu sağlık davranışlarının oluşmasında olumsuz yönleri ve oluşabilecek engelleri algılaması anlamına gelmektedir.

- Sağlık motivasyonu; bireyin sağlığını sürdürmesi ve geliştirmesi için motive olma durumudur.

- Güven (öz-yeterlilik); bireyin sağlık davranışı göstermesindeki yeterliliği anlamına gelmektedir.

- Özvarış (2011) ise “Sağlık İnanç Modeli"ni oluşturan kavramları şu şekilde sıralamıştır:

- Algılanan Duyarlılık; bireyin hastalığa yakalanabilme olasılığı konusundaki inancıdır. Algılanan duyarlılık fazla ise önleyici tedbirlere başvurma ihtimali de fazladır.

- Algılanan Ciddiyet; bireyin hastalığa yakalanabilme olasılığı konusundaki ciddiyetidir. Alglanan ciddiyet düzeyi fazla ise önleyici tedbirlere başvurma ihtimali de fazladır.

- "Alg1lanan duyarlılık" ve "algılanan ciddiyet" durumları, "algılanan tehdit"i oluşturur. Algılanan tehdidin oluşma düzeyinde ise; kişisel (demografik, sosyo-psikolojik durum vb.) ve çevresel (medya, arkadaş vb.) faktörler etkili olmaktadır.

- Değişikliğe Neden Olan Faktörler; demografik değişkenler (yaş, cinsiyet vb.), sosyo-psikolojik değişkenler (sosyal sınıf, kişisel yapı 
vb.) ve yapısal değişkenler (bilgi, deneyim vb.) davranışı değiştiren etmenlerdendir.

- Algılanan Yarar; bireyin önleyici tedbirlerin veya koruyucu sağlık davranışlarının, hastalığa yakalanma ihtimalini düşürmedeki faydasina olan inanci ve algisidır.

- Algılanan Engeller; bireyin önleyici tedbirleri veya koruyucu sağlık davranışlarını göstermesini engelleyen durum ve algılardır.

- "Algilanan fayda" "algilanan engeller"e göre fazla ise koruyucuönleyici sağlık davranıslarının görülme ihtimali o kadar fazladır. Tam tersi durumda ise engeller sağllk davranışının sergilenme ihtimalini ve sağlık inancını düşürecektir.

- Eyleme Geçiriciler; bireyi önleyici tedbir davranışları göstermeye yönelten uyarıcılardır. Bunlar içsel (hastalık belirtileri vb.) olabileceği gibi dışsal (medya, arkadaş vb.) de olabilir. Uyarıcılar fazla olmas1 durumunda bireyin tedbirli davranıp koruyucu-önleyici sağlık davranışı göstermesi beklenir.

- Öz-Yeterlilik Algısı; bireyin koruyucu-önleyici sağlık davranışlarını sergileyebilmesi için kendine olan inancıdır. Bu inancın fazla olması koruyucu-önleyici sağlık davranışlarını sergileme ihtimalini arttıracaktır. Az olması ise koruyucu-önleyici sağlık davranışlarının sergilenme ihtimalini düşürerek hastalığa yakalanma ihtimalini arttıracaktır.

\section{Araștırmanın Amacı}

Tüm dünyada COVID-19 salgınının yaşanması sebebiyle olağanüstü acil durum önlemleri alındı. Günlük hayatımızda eski normal/ yeni normal kavramları oluştu. Bireysel olarak hazırlıklı olmanın, kendimizi ve yakın çevremizi korumanın tartışıldığı gündem içerisinde bulunuyoruz. Bu araştırma ile öğretmen ve okul yöneticilerinin salgın sürecindeki bireysel hazırlık algı düzeylerinin tespit edilmesi amaçlanmaktadır. Belirtilen genel amaç çerçevesinde bu araştırmada aşağıdaki alt amaç sorularına cevap aranacaktir.

1. Katılımcıların salgınlara yönelik bireysel hazırlık algıları ne düzeydedir? 
2. Katılımcıların salgınlara bireysel hazırlık algıları ile yaş değişkeni arasında anlamlı düzeyde farklılık var mıdır?

3. Katılımciların salgınlar hakkındaki bireysel hazırlık algıları ile cinsiyet değişkeni arasında anlamlı düzeyde farklılık var mıdır?

4. Katılımcıların salgınlar hakkındaki bireysel hazırlık algıları ile öğrenim durumu değişkeni arasında anlamlı düzeyde farklılık var mıdır?

5. Katılımciların salgınlar hakkındaki bireysel hazırlık algıları ile medeni durum değişkeni arasında anlamlı düzeyde farklılık var mıdır?

6. Katılımcıların salgınlar hakkındaki bireysel hazırlık algıları ile çocuk sahibi olup olmaması durumu arasında anlamlı düzeyde farklılık var midır?

7. Katılımcların salgınlar hakkındaki bireysel hazırlık algıları ile aylık gelir düzeyi arasında anlamlı düzeyde farklılık var mıdır?

8. Katılımciların salgınlar hakkındaki bireysel hazırlık algıları ile unvan değişkeni arasında anlamlı düzeyde farklılık var mıdır?

\section{Yöntem}

\section{Araştırmanın Modeli}

Öğretmenlerin ve okul yöneticilerinin salgınlar hakkında bireysel hazırlık algilarının Sağlık İnanç Modeli'ne dayalı olarak çeşitli değişkenlere göre incelenmesinin amaçlandığı bu araştırmada nicel araştırma yöntemlerinden olan betimsel tarama modeli kullanılmıştır. Bu kapsamda Kahramanmaraş, Şanlıurfa ve Adıyaman illeri Merkez İlçelerinde bulunan devlet okullarında görev yapan 403 öğretmen ve okul yöneticisine ulaşılmıştır. Betimsel tarama modeli; büyük gruplara ulaşılabilen araştırmalarda, katılımcıların bir olay veya olguya yönelik görüşlerinin alındığı ve sonucunda olay veya olguya yönelik betimleme imkânı veren araştırma modelidir (Büyüköztürk, Kılıç, Akgün, Karadeniz ve Demirel, 2017, s.184; Karakaya, 2012, s.59).

\section{Araştırmanın Evreni ve Örneklemi}

Araştırmanın evrenini Kahramanmaraş ve Şanlıurfa İlleri Merkez İlçeleri ile Adıyaman İli Merkez İlçesinde bulunan devlet okulları oluşturmaktadır. Araştırmanın örneklemini ise seçkisiz örneklem yöntemi ile seçilen 403 öğ- 
retmen ve okul yöneticisi oluşturmaktadır. Analizler 403 veri üzerinden gerçekleştirilmiştir. Katılımcılara sorulan demografik soruların yanıtları, katılımcları tanımak amacıyla Tablo 1'de gösterilmiştir.

Tablo 1. Katılımcılara İlişkin Demografik Bilgiler

\begin{tabular}{|c|c|c|c|}
\hline Kategoriler & Gruplar & $f$ & $\%$ \\
\hline \multirow[t]{5}{*}{ Yaş } & 30 yaş altı & 114 & 28,3 \\
\hline & $31-40$ yaş & 200 & 49,6 \\
\hline & $41-50$ yaş & 73 & 18,1 \\
\hline & 51 ve üstü & 16 & 4,0 \\
\hline & Toplam & 403 & 100,0 \\
\hline \multirow[t]{3}{*}{ Cinsiyet } & Kadın & 170 & 42,2 \\
\hline & Erkek & 233 & 57,8 \\
\hline & Toplam & 403 & 100,0 \\
\hline \multirow[t]{4}{*}{ Öğrenim Durumu } & Yüksekokul & 19 & 4,7 \\
\hline & Lisans & 312 & 77,4 \\
\hline & Lisansüstü & 72 & 17,9 \\
\hline & Toplam & 403 & 100,0 \\
\hline \multirow[t]{3}{*}{ Medeni Durum } & Evli & 291 & 72,2 \\
\hline & Bekar & 112 & 27,8 \\
\hline & Toplam & 403 & 100,0 \\
\hline \multirow[t]{4}{*}{ Çocuk Bilgisi } & 0 & 146 & 36,4 \\
\hline & $1-2$ & 194 & 48,4 \\
\hline & $3-4$ & 61 & 15,2 \\
\hline & Toplam & 403 & 100,0 \\
\hline \multirow[t]{4}{*}{ Aylık Gelir } & 4500 altı & 85 & 21,1 \\
\hline & $4500-5500$ & 206 & 51,1 \\
\hline & 5500 ve üstü & 112 & 27,8 \\
\hline & Toplam & 403 & 100,0 \\
\hline \multirow[t]{4}{*}{ Unvan } & Öğretmen & 337 & 85,0 \\
\hline & Müdür yardımcısı & 20 & 5,0 \\
\hline & Müdür & 40 & 10,0 \\
\hline & Toplam & 397 & 100,0 \\
\hline
\end{tabular}

Tablo 1'de katılımcılara ait kişisel bilgiler yer almakta ve bazı değişkenlerin toplam sayısının farklı olduğu görülmektedir. Bu durumun sebebi; bazı katılımcıların o değişkene ait soruyu yanıtsız bırakmasından kaynaklanmaktadır. Yaş değişkeni incelendiğinde $114(\% 28,3)$ katılımcının 30 yaş altı grubunda; $200(\% 49,6)$ katılımcının 31-40 yaş arası grubunda; 73 (\%18,1) katılımcının 41-50 yaş arası grubunda ve $16(\% 4,0)$ katılımcının 51 yaş ve üzeri grubunda yer aldığ görülmektedir. Cinsiyet değişkeninde katılımcıların 170'i $(\% 42,2)$ kadın iken; 233'ü $(\% 57,8)$ erkektir. Mezuniyet değişkeni 
incelendiğinde $19(\% 4,7)$ katılımcının yüksekokul mezunu; $312(\% 77,4)$ katılımcının lisans mezunu ve $72(\% 17,9)$ katılımcının lisansüstü mezunu olduğu gözlenmektedir. Medeni durum değişkeninde katılımcıların 291'i $(\% 72,2)$ evli ve 112 'si $(\% 27,8)$ bekardır. Katılımcıların 146 'sının $(\% 36,2)$ hiç çocuğu bulunmamakta; 194 'ünün (\%48,1) 1 ya da 2 çocuğu; $61^{\prime}$ inin $(\% 15,1) 3$ ya da 4 çocuğu bulunmaktadır. Araştırmaya katılanların 85 'inin $(\% 21,1)$ geliri 4.500 TL'nin altında yer alırken; 206'sının (\%51,1) geliri 4.500 TL5.500TL aralığında ve 112 'sinin $(\% 27,8)$ geliri 5.500 TL üzerindedir. Unvan değişkenine göre ise katılımcıların 337'si $(\% 83,6)$ öğretmen; 20 'si $(\% 5,0)$ müdür yardımcısı ve 40'ı $(\% 9,9)$ müdür olarak görev yapmaktadır.

\section{Veri Toplama Araçları}

Sağlık İnanç Modeli'ne dayalı olarak öğretmenler ve okul yöneticilerinin salgına yönelik bireysel hazırlık algılarının incelenmesinin amaçlandığı bu araştırmada katılımcılara iki bölümden oluşan form doldurulması istenmiştir. Bu formun ilk bölümünde katılımcların kişisel özelliklerini öğrenmeye yönelik 7 adet soru (yaş, cinsiyet, medeni durum, öğrenim durumu, çocuk bilgisi, unvan) yer almaktadır. Bu sorular araştırmada bağımsız değişken olarak kullanılmış olup değişkenler üzerinden çeşitli analizler gerçekleştirilmiştir.

İkinci bölümde ise İnal (2015) tarafından geliştirilen “Sağlık İnanç Modeli'ne Dayalı Acil Durumlara/Afetlere Bireysel Hazırlığa İlişkin Ölçek" kullanılmıştır. Ölçekteki "Acil Durumlar" ifadesi yerine acil durum çeşitlerinden olan "Salgın" kelimesi kullanılmıştır. 4. maddede yer alan "afet çantası" ifadesinde "maske, dezenfektan vb." içeriklerini kapsadığı belirtilmiştir. Bu kapsamda araştırmacılar tarafından depremlere yönelik olan sorular çıkar1larak veri toplanmıştır. 3, 7, 19, 27, 28, 30, 31, 32, 33 numaralı maddeler araştırma kapsamında değerlendirilmemiştir. Ölçeğin orijinal halinde 33 madde ve 6 boyut yer alırken; bu araştırmada 24 madde ve 6 boyut yer almaktadır. Ölçek içerisinde olumsuz ifadelerin yer almasından dolayı 4, 5, 7, 9, 14, 15, $16,17,18,19,20,24,27,28$ ve 32. maddelerde ters kodlama yapılmıştır.

Ölçekten alınacak en yüksek puan 120; en düşük puan ise 24 olarak değerlendirilmektedir. Ölçekten alınan puanın yüksek olması salgına yönelik bireysel hazırlık düzeyinin yüksek olması; ölçek puanının düşük olması salgına yönelik bireysel hazırlık düzeyinin düşük olması anlamı taşımakta- 
dır. (1) Kesinlikle katılmıyorum - (5) Kesinlikle katılıyorum aralığında olan 5'li Likert tipinden oluşmaktadır. Bununla birlikte ölçeğin 5'li Likert tipinden oluşmasından dolayı $(5-1=4 ; 4 / 5=0,80)$ hesaplaması ile belirli bir aralık oluşturulmuştur. Bu hesaba göre;

1,00-1,80 aralığıKesinlikle Katılmıyorum Düzeyi

1,81-2,60 aralığıKatılmıyorum Düzeyi

2,61-3,40 aralığ1Kararsızım Düzeyi

3,41-4,20 aralığıKatıllyorum Düzeyi

4,21-5,00 aralı̆̆ıKesinlikle Katılıyorum Düzeyi olarak belirlenmiş ve bunlara göre yorumlar yapılmıştır.Ölçeğin boyutları ve içerisinde yer alan maddeler Tablo 2.'de gösterilmiştir.

Tablo 2. Araştırmada Kullanılan Ölçeğe Ait Bilgiler

\begin{tabular}{lll}
\hline Ölçeğin Boyutları & Madde Numarası & Madde Sayısı \\
\hline Algılanan Duyarlılık & $1,2,3,4,5$ & 5 \\
Algılanan Ciddiyet & $6,7,8$ & 3 \\
Algılanan Yarar & $9,10,11$ & 3 \\
Algılanan Engeller & $12,13,14,15,16$, & 5 \\
Eyleme Geçiriciler & $17,18,19,20,21,22$ & 6 \\
Öz Yeterlilik & 23,24 & 2 \\
\hline
\end{tabular}

Araştırmada kullanılan ölçeğin alt boyutları ve madde numaraları ile madde sayıları Tablo 2'de gösterilmiştir. İnal'ın (2015) geliştirdiği ölçekte gerekli olan yapı ve kapsam geçerliliği çalışmaları gerçekleştirilmiştir. Açımlayıcı Faktör Analizi ve Doğrulayıcı Faktör Analizi ile faktörler belirlenip doğrulanmıştır. Yapılan analizler sonucunda elde edilen değerlerin yeterli olduğu araştırmacı tarafından raporlanmıştır (İnal, 2015). Bununla birlikte ölçeğin güvenirliği için Cronbach's Alpha değerleri incelenmiştir. Ölçeğin geneli için hesaplanan Alpha değeri ise 0,905'tir. Bu çalışma kapsamında ise ölçek genelindeki Cronbach's Alpha katsayısı 0,757 olarak hesaplanmıştır. $\mathrm{Bu}$ değerlerin 0,70 ve üstünde olması durumunun güvenirlik için yeterli ölçüde olduğu belirtilmiştir (Büyüköztürk, 2010). 


\section{Veri Analiz Yöntemi}

Sağlık İnanç Modeli'ne dayalı olarak öğretmenler ve okul yöneticilerinin salgına yönelik bireysel hazırlık algılarının incelenmesinin amaçlandığı bu araştırmada çeşitli demografik değişkenler bağımsız değişken olarak ele alınmış ve gerekli analizler yapılmıştır. Bu analizler kapsamında SPSS 21.0 programı kullanılmıştır. Frekans, yüzde alma, aritmetik ortalama, standart sapma gibi betimleyici istatiksel işlemlerden düzeyler ve dağılımlar bağlamında yararlanılmıştır.

Araştırmanın genel ve alt amaçları doğrultusunda veri analizleri yapmadan önce verilerin normallik varsayımları kontrol edilmiştir. Buna göre basıklık-çarpıklık değerleri, normallik testleri, Histogram, Q-Q Plot ve kutu grafikleri incelenmiştir. Ölçeğin geneli için bu beş durumdan ilki olan basıklık-çarpıklık değerlerinin incelenmesinde, çarpıklık ve basıklık değerlerinin standart hatalarına bölünmesi ile oluşan değerlerin (z skoru) $\pm 1,96$ değerlerinin arasında olduğu görülmüştür (Can, 2017, s.85). Normallik testlerinden Shapiro-Wilk testi $\mathrm{p}=0,067$ olarak hesaplanmıştır. Bu değerin 0,05'in üzerinde olması normallik varsayımının sağlandığına işaret etmektedir (Can, 2017, s.88). Histogram grafiğinde normal dağılımın olduğu görülmektedir. Q-Q Plot ve Kutu grafiklerinde uç değerlerin yer aldığ1 görülse de genel olarak normal dağılımın söz konusu olduğu gözlenmiştir. İncelemelerin sonucunda normallik varsayımın karşılandığı ve analiz sürecinde parametrik testlerden faydalanacağı sonucu ortaya çıkmıştır. Ancak bazı değişkenlerde veri sayısının az olduğu grupların yer alması sebebiyle parametrik olmayan test yöntemleri de kullanılmıştır. Bunlar; yaş, mezuniyet, ve unvan değişkenleridir.

Analizler gerçekleştirilirken parametrik test kullanılacağı durumlarda değişkenler iki gruptan oluşuyorken bağımsız örneklemler t-testi; ikiden fazla gruptan oluşuyorken ise tek yönlü varyans analizi ANOVA testinden faydalanılmıştır. Grupların sayısının az olduğu değişkenlerle analiz yapılacağı zaman parametrik olmayan testler kullanılmış olup bu değişkenler ikiden fazla gruplu değişken olduğu için yalnızca Kruskal-Wallis $\mathrm{H}$ testi kullanılmıştır. Kruskal-Wallis H testinde çıkan anlamlı farklılığı tespit edebilmek için Bonferroni düzeltmesinden yararlanılmıştır. ANOVA testinde çıkan anlamlı farklılığın hangi ikili gruplardan kaynaklı olduğunu bulabilmek amacıyla ise Post Hoc çoklu karşılaştırma testlerinden olan Scheffe testi 
kullanılmıştır. Verilerin analizinde $p=0,05$ anlamlılık düzeyi dikkate alınmiştır.

\section{Bulgular}

\section{Araştırma Problemi: Katılımcıların salgınlar hakkında bireysel hazırlık algıları ne düzeydedir?}

Tablo 2. Sağlık İnanç Modeli'ne Dayalı Olarak Öğretmenlerin ve Okul Yöneticilerinin Salgına Yönelik Bireysel Hazırlık Algılarmın Betimleyici İstatistiksel Bilgileri

\begin{tabular}{lllllll}
\hline Boyutlar & $n$ & $\boldsymbol{X}$ & SS & Sh & \multicolumn{2}{c}{$\begin{array}{c}\text { \%95 Güven } \\
\text { Üst Sinır }\end{array}$} \\
\hline AlgılananDuyarlılık & 403 & 4,01 & 0,544 & 0,02 & 3,96 & 4,07 \\
AlgılananCiddiyet & 403 & 3,81 & 0,794 & 0,03 & 3,74 & 3,89 \\
AlgılananYarar & 403 & 4,24 & 0,650 & 0,03 & 4,18 & 4,31 \\
AlgilananEngeller & 403 & 3,64 & 0,617 & 0,03 & 3,58 & 3,71 \\
Eyleme Geçiriciler & 403 & 3,61 & 0,615 & 0,03 & 3,54 & 3,66 \\
Öz Yeterlilik & 403 & 3,41 & 0,769 & 0,03 & 3,33 & 3,48 \\
Ölçek Toplam & 403 & 3,79 & 0,377 & 0,01 & 3,75 & 3,83 \\
\hline
\end{tabular}

Tablo 2'de görülmekte olan değerlere göre öğretmen ve okul yöneticilerinin salgına yönelik bireysel hazırlık algıları ölçek genelinde \%95 güven aralığındaki 3,75 - 3,83 alt ve üst sinırlarında $(X=3,79 ; S S=0,377)$ olarak hesaplamıştır. Bu değer, veri daha önce belirlenen aralıktan "Katılıyorum" düzeyine denk gelmektedir. Alt boyutlara bakıldığında "algilanan duyarllık" boyutu $(X=4,01$; SS=0,544) değerleri ile "Katıllyorum" düzeyinde; "algılanan ciddiyet" boyutu $(X=3,81 ; \mathrm{SS}=0,794)$ değerleri ile "Katıliyorum" düzeyinde; "algilanan yarar" boyutu $(X=4,24$; $S S=0,650)$ değerleri ile "Kesinlikle Katıliyorum" düzeyinde; "alglanan engeller" boyutu $(X=3,64$; SS=0,617) değerleri ile "Katıllyorum" düzeyinde; "eyleme geçiriciler" boyutu $(X=3,61$; SS=0,615) "Katılıyorum" düzeyinde ve "öz yeterlilik" boyutu $(X=3,41 ; S S=0,769)$ değerleri ile "Katılıyorum" düzeyinde olarak hesaplanmıştır. Sonuçlara bakıldığında alt boyutlarda genel olarak "Katılıyorum" düzeyi puan aralığının hakim olduğu, yalnızca "algılanan yarar" boyutu değerlerinin "Kesinlikle Katılıyorum" düzeyinde olduğu görülmektedir.

\section{Araştırma Problemi: Katılımcıların salgınlar hakkındaki bireysel hazır- lık algıları ile yaşı arasında anlamlı düzeyde farklılık var mıdır?}


Tablo 3'te yer alan analiz sonuçlarına göre ölçek genelinde öğretmenlerin ve okul yöneticilerinin salgına yönelik bireysel hazırlık düzeyleri yaş değişkeni kapsamında gruplar arasında anlamlı farklılık olduğu görülmektedir $\left[\chi^{2}(3)=9,936 ; p<0,05\right]$. Ortaya çıkan anlamlı farklılığın kaynağını tespit edebilmek amaciyla Bonferroni düzeltmesi sonuçlarına bakılmıştır. Sonuçlara göre 21-30 yaş ile 31-40 yaş grubu ve 31-40 yaş ile 41-50 yaş grubu arasında olan farklılıklardan kaynaklı olduğu gözlenmiştir. Sıra ortalamaları dikkate alındığında anlamlı farklılıkların her iki ikili grup için de 31-40 yaş arasındaki grup lehine olduğu söylenebilmektedir.

Tablo 3. Sağlık İnanç Modeli'ne Dayalı Olarak Öğretmenlerin ve Okul Yöneticilerinin Salgına Yönelik Bireysel Hazırlık Algılarının Yaş Değisskenine Göre Kruskal-Wallis H Testi Sonuçlarn

\begin{tabular}{|c|c|c|c|c|c|c|c|c|}
\hline Boyutlar & Yaş & $n$ & $X$ & SS & $\begin{array}{l}\text { Sira } \\
\text { ortalaması }\end{array}$ & Sd & $\chi^{2}$ & $p$ \\
\hline Algılanan & 21-30 yaş & 114 & 3,96 & 0,473 & 186,64 & 3 & 13,007 & $0,005^{* *}$ \\
\hline \multirow[t]{3}{*}{ Duyarlılık } & $31-40$ yaş & 200 & 4,09 & 0,564 & 217,32 & & & \\
\hline & $41-50$ yaş & 73 & 4,00 & 0,537 & 201,33 & & & \\
\hline & 51yaş+ & 16 & 3,61 & 0,622 & 122,97 & & & \\
\hline Algılanan & 21-30 yaş & 114 & 3,84 & 0,752 & 202,04 & 3 & 4,328 & 0,228 \\
\hline \multirow[t]{3}{*}{ Ciddiyet } & $31-40$ yaş & 200 & 3,86 & 0,802 & 210,10 & & & \\
\hline & 41-50 yaş & 73 & 3,73 & 0,856 & 189,80 & & & \\
\hline & 51yaş+ & 16 & 3,58 & 0,694 & 156,19 & & & \\
\hline Algılanan & $21-30$ yaş & 114 & 4,13 & 0,639 & 177,94 & 3 & 14,925 & $0,002^{* *}$ \\
\hline \multirow[t]{3}{*}{ Yarar } & $31-40$ yaş & 200 & 4,29 & 0,666 & 212,42 & & & \\
\hline & $41-50$ yaş & 73 & 4,37 & 0,611 & 225,01 & & & \\
\hline & 51yaş+ & 16 & 3,96 & 0,543 & 138,19 & & & \\
\hline Algilanan & $21-30$ yaş & 114 & 3,52 & 0,619 & 181,68 & 3 & 7,804 & 0,050 \\
\hline \multirow[t]{3}{*}{ Engeller } & $31-40$ yaş & 200 & 3,73 & 0,633 & 217,63 & & & \\
\hline & $41-50$ yaş & 73 & 3,61 & 0,564 & 191,14 & & & \\
\hline & 51yaş+ & 16 & 3,69 & 0,537 & 200,97 & & & \\
\hline Eyleme & $21-30$ yaş & 114 & 3,56 & 0,530 & 191,58 & 3 & 6,466 & 0,091 \\
\hline \multirow[t]{3}{*}{ Geçiriciler } & $31-40$ yaş & 200 & 3,67 & 0,650 & 212,64 & & & \\
\hline & 41-50 yaş & 73 & 3,51 & 0,640 & 181,29 & & & \\
\hline & 51yaş+ & 16 & 3,74 & 0,574 & 237,78 & & & \\
\hline Öz & 21-30 yaş & 114 & 3,45 & 0,530 & 206,35 & 3 & 4,039 & 0,257 \\
\hline \multirow[t]{3}{*}{ Yeterlilik } & $31-40$ yaş & 200 & 3,40 & 0,841 & 200,35 & & & \\
\hline & $41-50$ yaş & 73 & 3,36 & 0,743 & 187,82 & & & \\
\hline & 51yaş+ & 16 & 3,66 & 0,651 & 248,91 & & & \\
\hline Ölçek & 21-30 yaş & 114 & 3,73 & 0,329 & 184,40 & 3 & 9,936 & $0,019^{*}$ \\
\hline \multirow[t]{3}{*}{ Toplam } & $31-40$ yaş & 200 & 3,85 & 0,403 & 220,15 & & & \\
\hline & $41-50$ yaş & 73 & 3,76 & 0,360 & 186,79 & & & \\
\hline & 51yaş+ & 16 & 3,70 & 0,372 & 169,91 & & & \\
\hline
\end{tabular}


"Algılanan Duyarlılı" boyutuna bakıldığında yaş değişkenine göre gruplar arasında anlamlı farklılıkların olduğu görülmektedir. Ortaya çıkan farklılığın kaynağını bulabilmek amacıyla yapılan Bonferroni düzeltmesi sonucuna göre 21-30 yaş ile 31-40 yaş; 21-30 yaş ile 51 yaş ve üzeri; 31-40 yaş ile 51 yaş ve üzeri; 41-50 yaş ile 51 yaş ve üzeri ikili grupları arasında anlamlı düzeyde farklılıklar tespit edilmiştir. Buna göre anlamlı farklılıkların olduğu ikili grupların sıra ortalamalarına bakıldığında daha küçük yaş grubunda olan ögretmenlerin ve okul yöneticilerin lehine bir durum olduğu gözlenmiştir.

Tablo 3'te yer alan bir diğer anlamlı farklılığın olduğu alt boyut ise "Algllanan Yarar" boyutudur. Yaş değişkeni açısından hangi gruplardan dolayı anlamlı farklılı̆̆ın ortaya çıktığının tespiti için tespiti için Bonferroni düzeltmesi sonuçları incelenmiştir. İncelemeler sonucunda; 21-30 yaş ile 31-40 yaş; 21-30 yaş ile 41-50 yaş; 31-40 yaş ile 51 yaş ve üzeri; $41-50$ yaş ile 51 yaş ve üzeri ikili gruplarından kaynaklanan anlamlı farklılık olduğu gözlenmiştir. İnceleme sonuçları doğrultusunda 21-30 yaş ile 31-40 yaş ikili gruplarında anlamlı farklılık 31-40 yaş arası grubunun lehinedir. 21-30 yaş ile 41-50 yaş arası ikili gruplarındaki anlamlı farklılık 41-50 yaş grubu lehinedir. 3140 yaş ile 51 yaş ve üzeri ikili gruplarındaki anlamlı farklılık 31-40 yaş grubunun lehinedir. Son olarak 41-50 yaş ile 51 yaş ve üzeri ikili gruplarında ortaya çıkan anlamlı farklılık 41-50 yaş grubunun lehinedir.

\section{Araştırma Problemi: Katılımcıların salgınlar hakkındaki bireysel hazır- lık algıları ile cinsiyeti arasında anlamlı düzeyde farklılık var mıdır?}

Tablo 4'te öğretmenlerin ve okul yöneticilerinin salgına yönelik bireysel hazırlık algılarının cinsiyet değişkinindeki grupların ortalama puanlarına göre gruplar arasında anlamlı düzeyde bir farklılık olup olmadığının tespiti için uygulanan t-testi sonuçları bulunmaktadır. Buna göre ölçek genelinde grupların ortalama puanları arasında anlamlı düzeyde farklılık tespit edilmiştir [ $\left.t_{(401)}=3,277 ; p<0,01\right]$. Ortaya çıkan bu farklılıkta ortalamalar dikkate alındığında kadınların lehine bir durum söz konusu olarak gözlenmektedir. Ölçeğin alt boyutlarına bakıldığında "Alg̨lanan Duyarlılı" $[\mathrm{t}(401)=3,769 ; p<$ $0,01]$ ve "Algllanan Ciddiyet" [ $\left.\mathbf{t}_{(401)}=5,267 ; p<0,01\right]$ boyutlarında grupların ortalama puanları arasında manidar bir farklılık ortaya çıkmıştır. Alt boyutlarda ortaya çıkan bu farklılıklarda da ölçek genelinde olduğu gibi kadınla- 
rın lehine bir durum söz konusudur. Başka bir deyişle; kadın öğretmen ve okul yöneticilerinin erkek öğretmen ve okul yöneticilerine göre salgına yönelik bireysel hazırlık algı düzeyleri anlamlı bir şekilde daha yüksektir.

Tablo 4. Sağlık İnanç Modeli'ne Dayalı Olarak Öğretmenlerin ve Okul Yöneticilerinin Salgına Yönelik Bireysel Hazırlık Algılarının Cinsiyet Değişkenine Göre t-testi Sonuçlarn

\begin{tabular}{|c|c|c|c|c|c|c|c|}
\hline Boyutlar & Cinsiyet & $n$ & $\bar{X}$ & SS & $t$ & sd & $p$ \\
\hline Algilanan & Kadın & 170 & 4,13 & 0,467 & 3,769 & 401 & $0,000^{* *}$ \\
\hline Duyarlılık & Erkek & 233 & 3,93 & 0,581 & & & \\
\hline Algilanan & Kadın & 170 & 4,05 & 0,690 & 5,267 & 401 & $0,000^{* *}$ \\
\hline Ciddiyet & Erkek & 233 & 3,65 & 0,824 & & & \\
\hline Alg1lanan & Kadın & 170 & 4,26 & 0,569 & 0,436 & 401 & 0,663 \\
\hline Yarar & Erkek & 233 & 4,24 & 0,705 & & & \\
\hline Alg1lanan & Kadın & 170 & 3,68 & 0,583 & 0,922 & 401 & 0,357 \\
\hline Engeller & Erkek & 233 & 3,62 & 0,642 & & & \\
\hline Eyleme & Kadın & 170 & 3,66 & 0,577 & 1,332 & 401 & 0,184 \\
\hline Geçiriciler & Erkek & 233 & 3,58 & 0,641 & & & \\
\hline Öz & Kadın & 170 & 3,37 & 0,714 & $-0,949$ & 401 & 0,343 \\
\hline Yeterlilik & Erkek & 233 & 3,44 & 0,807 & & & \\
\hline Ölçek & Kadın & 170 & 3,86 & 0,342 & 3,277 & 401 & $0,001^{* *}$ \\
\hline Toplam & Erkek & 233 & 3,74 & 0,394 & & & \\
\hline
\end{tabular}

${ }^{*} p<0,05 \quad * * p<0,01$

4. Araştırma Problemi: Katılımcıların salgınlar hakkındaki bireysel hazırlık algıları ile öğrenim durumu arasında anlamlı düzeyde farklılık var midir?

Tablo 5'te yer alan Kruskal-Wallis $H$ testi sonuçlarına göre öğretmen ve okul yöneticilerinin mezuniyet değişkeni ile salgınlara yönelik bireysel hazırlık algı düzeyleri arasında ölçek genelinde $\left[\chi^{2}(2)=3,031 ; p>0,05\right]$; "Algılanan Duyarlilik" boyutunda $\left[\chi^{2}(2)=4,261 ; p>0,05\right]$; "Algilanan Yarar" boyutunda $\left[\chi^{2}(2)=3,723 ; p>0,05\right]$; "Algilanan Engeller" boyutunda $\left[\chi^{2}(2)=1,408 ; p>\right.$ $0,05]$; "Eyleme Geçiriciler" boyutunda $\left[\chi^{2}(2)=2,739 ; p>0,05\right]$ ve "Öz Yeterlilik" boyutunda $\left[\chi^{2}(2)=4,264 ; p>0,05\right]$ anlamlı düzeyde bir farklılığının olmadığı tespit edilmiştir.

"Algılanan Ciddiyet" boyutunda grupların ortalama puanlarına göre anlamlı düzeyde farklılık olduğu görülmektedir $\left[\chi^{2}(2)=9,783 ; p<0,01\right]$. Bu farklılığının hangi ikili gruplardan kaynaklandığını görebilmek amacıyla Kruskal-Wallis H testindeki Bonferroni düzeltmesi sonuçlarına bakılmıştır. İnce- 
lenen sonuçlar çerçevesinde yüksekokul mezunu ile lisans mezunu ve yüksekokul mezunu ile lisansüstü mezunu ikili grupları arasında anlamlı farklılıklar olduğu gözlenmiştir. Sıra ortalamaları dikkate alındığında ölçeğin algilanan ciddiyet boyutu için yüksekokul mezunu ile lisans mezunu ikili gruplarında lisans mezunu olanların lehine; yüksekokul mezunu ile lisansüstü mezunu ikili gruplarında lisansüstü mezunu olanların lehine anlamlı farklilık mevcuttur.

Tablo 5. Sağlık İnanç Modeli'ne Dayalı Olarak Öğretmenlerin ve Okul Yöneticilerinin Salgına Yönelik Bireysel Hazırlık Algılarının Öğrenim Durumu Değişkenine Göre Kruskal-Wallis H Testi Sonuçlar

\begin{tabular}{lllllllll}
\hline Boyutlar & ÖğrenimDurumu & $n$ & $\bar{X}$ & SS & S1raortalaması & sd & $\chi^{2}$ & $p$ \\
\hline Algilanan & Yüksekokul & 19 & 3,94 & 0,604 & 192,21 & 2 & 5,426 & 0,066 \\
Duyarlılıkk & Lisans & 312 & 3,99 & 0,542 & 195,97 & & & \\
& Lisansüstü & 72 & 4,16 & 0,520 & 230,71 & & & \\
\hline Algilanan & Yüksekokul & 19 & 3,40 & 0,634 & 132,26 & 2 & 9,783 & $0,008^{* *}$ \\
Ciddiyet & Lisans & 312 & 3,82 & 0,767 & 200,99 & & & \\
& Lisansüstü & 72 & 3,92 & 0,914 & 224,78 & & & \\
\hline Algilanan & Yüksekokul & 19 & 4,23 & 0,609 & 192,79 & 2 & 3,723 & 0,155 \\
Yarar & Lisans & 312 & 4,22 & 0,658 & 197,19 & & & \\
& Lisansüstü & 72 & 4,37 & 0,619 & 225,26 & & & \\
\hline Algilanan & Yüksekokul & 19 & 3,55 & 0,388 & 172,32 & 2 & 1,408 & 0,495 \\
Engeller & Lisans & 312 & 3,66 & 0,608 & 204,35 & & & \\
& Lisansüstü & 72 & 3,64 & 0,705 & 199,64 & & & \\
\hline Eyleme & Yüksekokul & 19 & 3,75 & 0,522 & 229,32 & 2 & 2,739 & 0,254 \\
Geçiriciler & Lisans & 312 & 3,59 & 0,604 & 197,02 & & & \\
& Lisansüstü & 72 & 3,66 & 0,685 & 216,36 & & & \\
\hline Öz & Yüksekokul & 19 & 3,74 & 0,788 & 254,21 & 2 & 4,264 & 0,119 \\
Yeterlilik & Lisans & 312 & 3,39 & 0,728 & 198,71 & & & \\
& Lisansüstü & 72 & 3,43 & 0,917 & 202,46 & & & \\
\hline Ölçek & Yüksekokul & 19 & 3,76 & 0,332 & 194,63 & 2 & 3,031 & 0,220 \\
Toplam & Lisans & 312 & 3,78 & 0,373 & 197,46 & & & \\
& Lisansüstü & 72 & 3,86 & 0,401 & 223,60 & & & \\
\hline
\end{tabular}

${ }^{*} p<0,05 \quad{ }^{* *} p<0,01$

\section{Araştırma Problemi: Katılımcıların salgınlar hakkındaki bireysel hazır- lık algıları ile medeni durumu arasında anlamlı düzeyde farklılık var midır?}

Tablo 6'da yer alan sonuçlar, öğretmenlerin ve okul yöneticilerinin salgına yönelik bireysel hazırlık algı düzeylerinin medeni durum değişkenindeki 
grupların ortalamaları arasında anlamlı düzeyde farklılık olup olmadığının tespiti için yapılan t-testi sonuçlarıdır.

Tablo 6. Sağlık İnanç Modeli'ne Dayalı Olarak Öğretmenlerin ve Okul Yöneticilerinin Salgına Yönelik Bireysel Hazırlık Algılarının Medeni Durum Değişkenine Göre t-Testi Sonuçlan

\begin{tabular}{|c|c|c|c|c|c|c|c|}
\hline Boyutlar & $\begin{array}{l}\text { Medeni } \\
\text { Durum }\end{array}$ & $n$ & $\bar{X}$ & SS & $t$ & sd & $p$ \\
\hline Algilanan & Evli & 291 & 4,04 & 0,558 & 1,474 & 401 & 0,141 \\
\hline Duyarlılık & Bekar & 112 & 3,95 & 0,502 & & & \\
\hline Algilanan & Evli & 291 & 3,84 & 0,806 & 0,846 & 401 & 0,398 \\
\hline Ciddiyet & Bekar & 112 & 3,76 & 0,763 & & & \\
\hline Algilanan & Evli & 291 & 4,27 & 0,763 & 1,333 & 401 & 0,183 \\
\hline Yarar & Bekar & 112 & 4,18 & 0,680 & & & \\
\hline Algilanan & Evli & 291 & 3,69 & 0,599 & 2,006 & 401 & $0,046^{*}$ \\
\hline Engeller & Bekar & 112 & 3,55 & 0,655 & & & \\
\hline Eyleme & Evli & 291 & 3,66 & 0,603 & 2,468 & 401 & $0,014^{*}$ \\
\hline Geçiriciler & Bekar & 112 & 3,49 & 0,634 & & & \\
\hline Öz & Evli & 291 & 3,35 & 0,784 & $-2,506$ & 401 & $0,013^{*}$ \\
\hline Yeterlilik & Bekar & 112 & 3,57 & 0,712 & & & \\
\hline Ölçek & Evli & 291 & 3,82 & 0,369 & 2,223 & 401 & $0,027^{*}$ \\
\hline Toplam & Bekar & 112 & 3,73 & 0,392 & & & \\
\hline
\end{tabular}

Buna göre ölçek genelinde $\left[\mathrm{t}_{(401)}=2,223 ; p<0,05\right]$; "Algılanan Engeller" boyutunda $\left[\mathrm{t}_{(401)}=2,006 ; p<0,05\right]$; "Eyleme Geçiriciler" boyutunda $\left[\mathrm{t}_{(401)}=2,468 ; p\right.$ $<0,05]$ ve "Öz Yeterlilik" boyutunda $\left[\mathrm{t}_{(401)}=-2,506 ; p<0,05\right]$ anlamlı düzeyde farklılıklar olduğu görülmektedir. Ölçeğin alt boyutlarından olan "Algılanan Duyarlilı" $\left[\mathrm{t}_{(401)}=1,474 ; p>0,05\right]$; "Algilanan Ciddiyet" $\left[\mathrm{t}_{(401)}=0,846 ; p>0,05\right]$ ve "Algilanan Yarar" [ $\left.\mathrm{t}_{(401)}=1,333 ; p>0,05\right]$ boyutlarında ise anlamlı düzeyde farklılık görülmemiştir. Ölçek genelinde, "Algılanan Engeller" boyutunda ve "Eyleme Geçiriciler" boyutunda ortaya çıkan anlamlı farklılıklar için ortalamalar değerlendirildiğinde evli olan grubun lehine bir durum söz konusudur. Ancak "Öz Yeterlilik" boyutundaki anlamlı farklılık bekâr olan grubun lehinedir. 
6. Araştırma Problemi: Katılımcıların salgınlar hakkındaki bireysel hazırlık algıları ile çocuk sahibi olup olmaması durumu arasında anlamlı düzeyde farklılık var midır?

Tablo 7. Sağhk İnanç Modeli'ne Dayalı Olarak Öğretmenlerin ve Okul Yöneticilerinin Salgına Yönelik Bireysel Hazırlık Algılarının Çocuk Sayısı Değişkenine Göre ANOVA Sonuçları

\begin{tabular}{|c|c|c|c|c|c|c|c|c|c|c|}
\hline Boyutlar & $\begin{array}{l}\text { Çocuk } \\
\text { sayısı }\end{array}$ & $n$ & $X$ & SS & $\begin{array}{l}\text { Varyansın } \\
\text { Kaynağ1 }\end{array}$ & $\begin{array}{l}\text { Kareler } \\
\text { Toplamı }\end{array}$ & sd & $\begin{array}{l}\text { Kareler } \\
\text { ort. }\end{array}$ & $F$ & $p$ \\
\hline Algilanan & 0 & 146 & 4,01 & 0,504 & Gruplararası & 0,899 & 2 & 0,450 & 1,516 & 0,221 \\
\hline \multirow[t]{2}{*}{ Duyarlılık } & $1-2$ & 194 & 4,06 & 0,550 & Gruplariçi & 118,091 & 398 & 0,297 & & \\
\hline & $3-4$ & 61 & 3,92 & 0,618 & Toplam & 118,991 & 400 & & & \\
\hline Algilanan & 0 & 146 & 3,84 & 0,711 & Gruplararası & 0,511 & 2 & 0,255 & 0,405 & 0,667 \\
\hline \multirow[t]{2}{*}{ Ciddiyet } & $1-2$ & 194 & 3,83 & 0,838 & Gruplariçi & 250,997 & 398 & 0,631 & & \\
\hline & $3-4$ & 61 & 3,74 & 0,839 & Toplam & 251,508 & 400 & & & \\
\hline Algilanan & 0 & 146 & 4,22 & 0,668 & Gruplararası & 0,301 & 2 & 0,151 & 0,354 & 0,702 \\
\hline \multirow[t]{2}{*}{ Yarar } & $1-2$ & 194 & 4,26 & 0,663 & Gruplariçi & 169,650 & 398 & 0,426 & & \\
\hline & $3-4$ & 61 & 4,30 & 0,580 & Toplam & 169,951 & 400 & & & \\
\hline Algilanan & 0 & 146 & 3,58 & 0,612 & Gruplararası & 1,618 & 2 & 0,809 & 2,123 & 0,121 \\
\hline \multirow[t]{2}{*}{ Engeller } & $1-2$ & 194 & 3,71 & 0,619 & Gruplariçi & 151,623 & 398 & 0,381 & & \\
\hline & $3-4$ & 61 & 3,59 & 0,624 & Toplam & 153,241 & 400 & & & \\
\hline Eyleme & 0 & 146 & 3,57 & 0,637 & Gruplararası & 1,921 & 2 & 0,961 & 2,552 & 0,079 \\
\hline \multirow[t]{2}{*}{ Geçiriciler } & $1-2$ & 194 & 3,59 & 0,624 & Gruplariçi & 149,807 & 398 & 0,376 & & \\
\hline & $3-4$ & 61 & 3,77 & 0,513 & Toplam & 151,728 & 400 & & & \\
\hline Öz & 0 & 146 & 3,49 & 0,702 & Gruplararası & 1,189 & 2 & 0,595 & 1,001 & 0,369 \\
\hline \multirow[t]{2}{*}{ Yeterlilik } & $1-2$ & 194 & 3,37 & 0,822 & Gruplariçi & 236,428 & 398 & 0,594 & & \\
\hline & $3-4$ & 61 & 3,39 & 0,759 & Toplam & 237,617 & 400 & & & \\
\hline Ölçek & 0 & 146 & 3,77 & 0,385 & Gruplararası & 0,114 & 2 & 0,057 & 0,399 & 0,671 \\
\hline \multirow[t]{2}{*}{ Toplam } & $1-2$ & 194 & 3,81 & 0,380 & Gruplariçi & 57,027 & 398 & 0,143 & & \\
\hline & $3-4$ & 61 & 3,80 & 0,359 & Toplam & 57,141 & 400 & & & \\
\hline
\end{tabular}

${ }^{*} p<0,05 \quad * * p<0,01$

Tablo 7'de öğretmen ve okul yöneticilerinin salgınlara yönelik bireysel hazırlık algı düzeylerinin çocuk sayısı değişkenine göre belirlenen gruplar arasında anlamlı düzeyde bir fark olup olmadığının tespiti için uygulanan ANOVA testi sonuçları yer almaktadır. Sonuçlar incelendiğinde $p=0,05$ anlamlılık düzeyine göre ölçek genelinde $\left[F_{(2-398)}=0,399 ; p>0,05\right]$ ve tüm alt boyutlarda anlamlı farklılık olmadığı gözlenmiştir.

\section{Araştırma Problemi: Katılımcıların salgınlar hakkındaki bireysel hazır- lık algıları ile aylık gelir düzeyi arasında anlamlı düzeyde farklılık var midır?}

Tablo 8'de yer alan bilgiler doğrultusunda öğretmenlerin ve okul yöneticilerin salgınlara yönelik bireysel hazırlık algılarının aylık gelir düzeyine göre 
anlamlı bir farklılığa yol açıp açmadığı sorusuna ANOVA testi ile cevap arandığ 1 görülmektedir. Analiz sonuçlarına göre ölçek genelinde $\left[F_{(2-400)}=\right.$ 1,008; $p>0,05]$; "Algilanan Duyarlilı" boyutunda $[F(2-400)=1,047 ; p>0,05] ;$ " Algilanan Yarar" boyutunda [ $F(2-400)=0,469 ; p>0,05]$; "Algilanan Engeller" boyutunda $\left[F_{(2-400)}=2,418 ; p>0,05\right]$; "Eyleme Geçiriciler" boyutunda $\left[F_{(2-400)}=2,111\right.$; $p>0,05]$ ve "Öz Yeterlilik" boyutunda $\left[F_{(2-400)}=0,357 ; p>0,05\right]$ anlamlı düzeyde farklılık olmadığı tespit edilmiştir.

Tablo 8. Sağlık İnanç Modeli'ne Dayalı Olarak Öğretmenlerin ve Okul Yöneticilerinin Salgına Yönelik Bireysel Hazırlık Algılarının Aylık Gelir Düzeyi Değişkenine Göre ANOVA Sonuçlan

\begin{tabular}{|c|c|c|c|c|c|c|c|c|c|c|}
\hline Boyutlar & $\begin{array}{l}\text { GelirDüzeyi } \\
\text { (TL) }\end{array}$ & $n$ & $\bar{X}$ & SS & $\begin{array}{l}\text { Varyansın } \\
\text { Kaynağı }\end{array}$ & $\begin{array}{l}\text { Kareler } \\
\text { Toplamı } \\
\end{array}$ & sd & $\begin{array}{l}\text { Kareler } \\
\text { ortalaması }\end{array}$ & $F$ & $p$ \\
\hline Algilanan & 4500altı & 85 & 4,06 & 0,494 & Gruplararası & 0,620 & 2 & 0,310 & 1,047 & 0,352 \\
\hline \multirow[t]{2}{*}{ Duyarlılık } & $4500-5500$ & 206 & 4,03 & 0,533 & Gruplariçi & 118,372 & 400 & 0,296 & & \\
\hline & 5500üstü & 112 & 3,96 & 0,598 & Toplam & 118,991 & 402 & & & \\
\hline Algilanan & 4500altı & 85 & 3,90 & 0,727 & Gruplararası & 5,322 & 2 & 2,661 & 4,288 & $0,014^{*}$ \\
\hline Ciddiyet & $4500-5500$ & 206 & 3,89 & 0,753 & Gruplariçi & 248,233 & 400 & 0,621 & & \\
\hline \multirow[t]{2}{*}{ Yarar } & $4500-5500$ & 206 & 4,27 & 0,623 & Gruplariçi & 169,677 & 400 & 0,424 & & \\
\hline & 5500üstü & 112 & 4,26 & 0,751 & Toplam & 170,075 & 402 & & & \\
\hline Algilanan & 4500altı & 85 & 3,52 & 0,573 & Gruplararası & 1,832 & 2 & 0,916 & 2,418 & 0,090 \\
\hline \multirow[t]{2}{*}{ Engeller } & $4500-5500$ & 206 & 3,67 & 0,585 & Gruplariçi & 151,555 & 400 & 0,379 & & \\
\hline & 5500üstü & 112 & 3,71 & 0,696 & Toplam & 153,387 & 402 & & & \\
\hline Öz & 4500altı & 85 & 3,41 & 0,615 & Gruplararası & 0,424 & 2 & 0,212 & 0,357 & 0,700 \\
\hline \multirow[t]{2}{*}{ Yeterlilik } & $4500-5500$ & 206 & 3,39 & 0,768 & Gruplariçi & 237,536 & 400 & 0,594 & & \\
\hline & 5500üstü & 112 & 3,46 & 0,874 & Toplam & 237,960 & 402 & & & \\
\hline Ölçek & 4500altı & 85 & 3,75 & 0,352 & Gruplararası & 0,287 & 2 & 0,143 & 1,008 & 0,366 \\
\hline \multirow[t]{2}{*}{ Toplam } & $4500-5500$ & 206 & 3,82 & 0,366 & Gruplariçi & 56,878 & 400 & 0,142 & & \\
\hline & 5500üstü & 112 & 3,79 & 0,414 & Toplam & 57,164 & 402 & & & \\
\hline
\end{tabular}

${ }^{*} p<0,05 \quad{ }^{* *} p<0,01$

Bununla birlikte "Algllanan Ciddiyet" boyutunda grupların ortalamaları arasında anlamlı düzeyde bir farklılık olduğu görülmüştür $\left[F_{(2-400)}=4,288 ; p<\right.$ $0,05]$. Ortaya çıkan farklılığın hangi ikili gruplar arasında olduğunu tespit etmek için Post Hoc Çoklu Karşılaştırma testlerinden olan Scheffe ile analiz sağlanmıştır. Sonuçlar Tablo 9'da gösterilmiştir.

Tablo 9' daki sonuçlar sonrasında ölçeğin alt boyutlarından olan "Alg1lanan Ciddiyet" boyutundaki aylık gelir düzeyindeki grup ortalamaları arasında çıan anlamlı farklılık sonucunun hangi ikili gruplardan kaynaklandığının tespiti için yapılan Post Hoc çoklu karşılaştırma testi (Scheffe) sonuçları Tablo 9'da yer almaktadır. Sonuçlar incelendiğinde anlamlı farklı- 
lığın kaynağı; $p=0,05$ anlamlılık düzeyine göre aylık gelir düzeyi 4.500 $5.000 \mathrm{TL}$ arasında olan grup $(X=3,89)$ ile aylık gelir düzeyi $5.500 \mathrm{TL}$ ve üstü olan grup $(X=3,63)$ arasındaki farktır. Ortalamalar dikkate alındığında bu fark, 4.500-5.000 TL aylık geliri olan grubun lehine olarak görülmektedir.

Tablo 9. Algılanan Ciddiyet Boyutu Post Hoc Çoklu Karşılaştırma Analizi Sonuçlan

\begin{tabular}{llllll}
\hline \multirow{4}{*}{ Scheffe } & (I) Gruplar & (J) Gruplar & OrtalamaFark & Sh & $p$ \\
\cline { 2 - 6 } & 4500 altı & $4500-5500$ & 0,01685 & 0,10156 & 0,986 \\
& 5500 üstü & 0,26803 & 0,11332 & 0,062 \\
\cline { 2 - 6 } & $4500-5500$ & 4500 altı & $-0,01685$ & 0,10156 & 0,986 \\
& 5500 üstü & $0,25118^{*}$ & 0,09248 & 0,026 \\
\cline { 2 - 6 } & 5500 üstü & 4500 altı & $-0,26803$ & 0,11332 & 0,062 \\
& $4500-5500$ & $-0,25118^{*}$ & 0,09248 & 0,026 \\
\hline
\end{tabular}

${ }^{*} p<0,05{ }^{* *} p<0,01$

\section{Araştırma Problemi: Katılımcıların salgınlar hakkındaki bireysel hazır- lık algılanı ile unvanı arasında anlamlı düzeyde farklılık var mıdır?}

Tablo 10. Sağlık İnanç Modeli'ne Dayalı Olarak Öğretmenlerin ve Okul Yöneticilerinin Salgına Yönelik Bireysel Hazırlık Algılarının Unvan Değişkenine Göre Kruskal-Wallis H Testi Sonuçlarn

\begin{tabular}{|c|c|c|c|c|c|c|c|c|}
\hline Boyutlar & Unvan & $n$ & $\bar{X}$ & SS & SiraOrtalaması & sd & $x^{2}$ & $p$ \\
\hline Algilanan & Öğretmen & 337 & 4,02 & 0,537 & 200,48 & 2 & 0,555 & 0,758 \\
\hline Duyarlılık & Müdür & 40 & 3,95 & 0,606 & 186,30 & & & \\
\hline Algilanan & Öğretmen & 337 & 3,83 & 0,786 & 201,41 & 2 & 1,556 & 0,459 \\
\hline Ciddiyet & Müdür yrd & 20 & 3,88 & 0,759 & 200,93 & & & \\
\hline Algilanan & Öğretmen & 337 & 4,24 & 0,641 & 199,34 & 2 & 0,135 & 0,935 \\
\hline \multirow[t]{2}{*}{ Yarar } & Müdür yrd & 20 & 4,31 & 0,452 & 204,00 & & & \\
\hline & Müdür & 40 & 4,17 & 0,802 & 193,65 & & & \\
\hline Algilanan & Öğretmen & 337 & 3,67 & 0,584 & 202,52 & 2 & 2,177 & 0,337 \\
\hline Engeller & Müdür yrd & 20 & 3,42 & 0,759 & 174,35 & & & \\
\hline Geçiriciler & Müdür & 40 & 3,72 & 0,629 & 216,83 & & & \\
\hline Öz & Öğretmen & 337 & 3,39 & 0,750 & 195,56 & 2 & 3,140 & 0,208 \\
\hline \multirow[t]{2}{*}{ Yeterlilik } & Müdür yrd & 20 & 3,32 & 0,877 & 197,45 & & & \\
\hline & Müdür & 40 & 3,61 & 0,780 & 228,74 & & & \\
\hline Ölçek & Öğretmen & 337 & 3,79 & 0,366 & 200,04 & 2 & 0,395 & 0,821 \\
\hline \multirow[t]{2}{*}{ Toplam } & Müdür yrd & 20 & 3,77 & 0,378 & 202,75 & & & \\
\hline & Müdür & 40 & 3,78 & 0,465 & 188,34 & & & \\
\hline
\end{tabular}

${ }^{*} p<0,05{ }^{* *} p<0,01$ 
Tablo 10'da öğretmen ve okul yöneticilerin salgınlara yönelik bireysel hazırlık algı düzeylerinin unvan değişkenine göre anlamlı düzeyde bir farklılık oluşturup oluşturmadığının tespiti için yapılan Kruskal-Wallis H testi sonuçları yer almaktadır. Sonuçlar incelendiğinde ölçek genelinde $\left[\chi^{2}(2)=0,395 ; p>\right.$,05] ve tüm alt boyutlarda yap1lan analizler neticesinde anlamlı farklılık oluşmadığı görülmüştür. Buna göre; öğretmenlerin ve okul yöneticilerinin salgınlara yönelik bireysel hazırlık algı düzeyleri, ünvanlarının durumuna göre anlamlı düzeyde bir farklılık oluşturmamaktadır.

\section{Tartışma ve Sonuç}

Araştırma sonuçlarına göre; öğretmenlerin ve okul yöneticilerin salgına yönelik bireysel hazırlık algı düzeyleri ölçek genelinde $(X=3,79 ; S S=0,377)$ değeri ile "Katılıyorum" düzeyinde olduğu gözlenmiştir. Öğretmenlerin ve okul yöneticilerin salgına yönelik bireysel hazırlık algı düzeyleri yaş, cinsiyet, öğrenim durumu, medeni durum ve aylık gelir değişkenleri bakımından farklılaşmakta iken; çocuk sayısı ve unvan değişkenleri bakımından ise farklılaşmamaktadir.

Öğretmenlerin ve okul yöneticilerin salgına yönelik bireysel hazırlık alg1 düzeyleri, yaş değişkeni açısından; ölçek geneli ve "algılanan yarar" boyutunda 21-30 yaş ile 31-40 yaş ikili gruplarında 31-40 yaş lehine; 21-30 yaş ile 41-50 yaş arası ikili gruplarında 41-50 yaş grubu lehine görülen anlamlı farklılıklar İnal (2015) tarafından yapılan araştırma sonuçlarıyla benzerlik göstermektedir. Bu sonuçlar yaşları daha ileri olan öğretmen ve okul yöneticilerinin salgına yönelik bireysel hazırlık algı düzeylerinin daha yüksek olduğunu göstermektedir.

Öğretmenlerin ve okul yöneticilerin salgına yönelik bireysel hazırlık alg1 düzeylerinde cinsiyet değişkeni açısından; ölçek geneli ve "algılanan duyarlılık" ve "algılanan ciddiyet" alt boyutlarında erkeklere göre kadınlar lehine anlamlı sonuç bulunmuştur. Bulunan farklılaşma sonuçlarına benzer sonuçlar İnal (2015) tarafından bulunmuş olup araştırma sonucunu destekliyor diyebiliriz. Bu sonuçlar kadın öğretmen ve okul yöneticilerinin erkek öğretmen ve okul yöneticilerine göre salgına yönelik bireysel hazırlık algı düzeylerinin daha yüksek olduğunu göstermektedir.

Öğretmenlerin ve okul yöneticilerin salgına yönelik bireysel hazırlık alg1 düzeylerinde öğrenim durumu değişkeni açısından; "algılanan ciddiyet" 
boyutunda "yüksekokul mezunu" ile "lisans mezunu" ikili gruplarında "lisans mezunu" olanların lehine; "yüksekokul mezunu" ile "lisansüstü mezunu" ikili gruplarında "lisansüstü mezunu" olanların lehine anlamlı farklılık bulunmuştur. Bu sonuçlar lisansüstü mezunu öğretmen ve okul yöneticilerinin daha düşük seviyedeki öğrenim durumlarına göre, salgına yönelik bireysel hazırlık algı düzeylerinin daha yüksek olduğunu gösteriyor. Bulunan farklılaşma sonuçlarına benzer sonuçlar İnal (2015) tarafından bulunmuş olup araştırma sonucunu desteklemektedir

Öğretmenlerin ve okul yöneticilerin salgına yönelik bireysel hazırlık algı düzeylerinde medeni durum değişkeni açısından; ölçek genelinde ve "alg1lanan engeller" boyutunda "eyleme geçiriciler" boyutunda ortaya çıkan anlamlı farklılıklar için ortalamalar değerlendirildiğinde evli olan grubun lehine; "öz yeterlilik" boyutunda ise anlamlı farklılık ise bekâr olan grubun lehinedir. İnal (2015) tarafından yapılan araştırmada da evli olan grup lehine anlamlı farklılıklar bulunarak benzer sonuçlar elde edilmiştir. Bu sonuçlar evli olan öğretmen ve okul yöneticilerinin bekar olanlara göre, salgına yönelik bireysel hazırlık algı düzeylerinin daha yüksek olduğunu göstermektedir.

Öğretmenlerin ve okul yöneticilerin salgına yönelik bireysel hazırlık alg1 düzeylerinde çocuk sayısı değişkeni açısından; ölçek genelinde ve alt boyutlarda anlamlı farklılık gözlenmemiştir. Bu sonuç öğretmen ve okul yöneticilerinin çocuk sayılarına göre, salgına yönelik bireysel hazırlık algı düzeylerinin değişmediğini göstermektedir. Bu değişkenle ilgili ulaşılabilen alanyazında bir çalışmaya rastlanılmamıştır.

Öğretmenlerin ve okul yöneticilerin salgına yönelik bireysel hazırlık algı düzeylerinde aylık gelir durumu değişkeni açısından; "algılanan ciddiyet" boyutunda anlamlı farklılık gelir düzeyi " 4.500 - 5.000 TL" arasında olan grup ile aylık gelir düzeyi "5.500 TL ve üstü" olan grup arasında "4.5005.000 TL" aylık geliri olan grubun lehine olarak gözlenmiştir. Bu değişkenle ilgili ulaşılabilen alanyazında bir çalışmaya rastlanılmamıştır.

Öğretmenlerin ve okul yöneticilerin salgına yönelik bireysel hazırlık algı düzeylerinde unvan değişkeni açısından; ölçek genelinde ve alt boyutlarda anlamlı farklılık gözlenmemiştir. Bu sonuç öğretmen ve okul yöneticilerinin unvan değişkenine göre, salgına yönelik bireysel hazırlık algı düzeylerinin değişmediğini göstermektedir. İnal (2015) ise yaptığı çalışmada üniversite çalışanları (öğretim görevlisi, araştırma görevlisi vb.) arasında unvana göre 
anlamlı farklılıklar bulmuştur. Bu durum, unvan değişkeninde göre salgına yönelik algıların kurumlara göre değişebileceğini gösteriyor olabilir.

$\mathrm{Bu}$ araştırmanın özellikle günümüzde "Pandemi" düzeyinde etkisi altında kaldığımız COVID-19 salgınında, bireylerin hastalığa yakalanmadan önceki hazırlıkları ve hastalığa yakalandıktan sonraki tedavi sürecinde öğretmenler ve okul yöneticilerinde farkındalık oluşturacağı; bu konuda yapılan araştırmalara da kaynaklık edeceği düşünülmektedir. Zira COVID-19 salgın, hastalığa yakalanan ve yakalanma riski olan insanların psikolojisini çok etkilediği için bu süreçte bireysel hazırlık farkındalığı her zamankinden daha fazla önem arz etmektedir. 


\title{
EXTENDED ABSTRACT
}

\section{Examining Teachers' and School Administrators' Perceptions of Individual Readiness for the Epidemic Based on the Health Belief Model}

\author{
Ahmet Kaya - Banu Moçoşoğlu - Halil İbrahim Sevim \\ Sütçü Imam University -MONE
}

The concept of health, which has more than one definition, means that individuals' being in good mental and social condition as well as their being in a goog physical condition.At the beginning, only the physical condition was considered with the concept of health, but since the 19th century, the mood status has also been used within the scope of the concept of health.Lifestyle is the result of people's conscious, controlled decisions, if we look at the situation in terms of health, this situation turns into a healthy lifestyle in the person only with the display of positive health behaviors. For a healthy lifestyle, individuals must believe and willingly exhibit these behaviors (WHO, 1984).Belief, which is the second of the concepts that make up the "Health Belief Model"; is another concept that expresses the continuous feelings and personal principles arising from the definitions of people about any subject within themselves.Behavior, on the other hand, means the expression of these beliefs (Peker \& Zengin, 2019).People's health is significantly affected by their health-related beliefs and behaviors. Health belief is the expression of one's thoughts and behaviors towards the state of being healthy or the state of illness.As a result of these beliefs, people's behaviors towards their health are shaped and as a result, they affect their health positively or negatively (Ünsal, 2017).

In recent years, the "Health Belief Model" has been developed to investigate the reason why people do not show much interest in the programs applied for the prevention and early diagnosis of diseases and at the same time to explain people's behaviors towards their health (Rosenstock, 1974).The Health Belief Model has been the most comprehensive model for explaining health behavior for the last 50 years.In the 1950s, public health researchers in the USA planned to develop a psychosocial 
model to make the health education given to the public in the field of health more efficient.Researchers found that demographic characteristics such as age, gender, socioeconomic level, and ethnicity are effective in people's health protection behaviors; but they noticed that even though health services are provided free of charge, people with low socioeconomic status use health care less.To explain the reasons for this picture, Rosenstock (1966) developed the "Health Belief Model" as usable for the first time (Gözüm, 2004; Gözüm \& Çapık, 2014).In the 1950s, some social psychologists developed the Health Belief Model as a preventative measure before becoming ill (Hochbaum, 1958).

Therefore, in this research; It is aimed to examine the individual preparedness perceptions of teachers and school administrators about epidemics according to various variables based on the Health Belief Model.

Descriptive survey model, which is one of the quantitative research methods, was used in this study, which aimed to examine the individual preparedness perceptions of teachers and school administrators about epidemics according to various variables based on the Health Belief Model.In this context, 403 teachers and school administrators working in public schools in the Central Districts of Kahramanmaraş, Şanlıurfa and Adiyaman were reached.The population of the research consists of public schools located in the Central Districts of Kahramanmaraş and Şanl1urfa Provinces and the Central District of Adiyaman Province.The sample of the study consists of 403 teachers and school administrators selected by random sampling method.Analyzes were carried out on 403 data.

Based on the Health Belief Model, in this study, which aimed to examine the individual preparedness perceptions of teachers and school administrators for the epidemic, the participants were asked to fill a form consisting of two parts.In the first part of this form, there are 7 questions (age, gender, marital status, education level, child number information, title) to learn the personal characteristics of the participants. These questions were used as independent variables in the research and various analyzes were carried out on the variables.In the second part, "The Health Belief Model-Based Scale on Individual Preparedness for Emergencies/Disasters" developed by İnal (2015) was used. 
In line with the general and sub-purposes of the research, the normality assumptions of the data were checked before performing data analysis.Accordingly, kurtosis-skewness values, normality tests, Histogram, Q-Q Plot and box plots were examined.Parametric and non-parametric tests were used to determine whether there was a significant difference or not with age, gender, educational status, marital status, having children, monthly income level and title information, which were used as independent variables within the scope of the research.Accordingly, descriptive statistical methods, independent samples t-Test, One-Way Analysis of Variance (ANOVA), Kruskal-Wallis $\mathrm{H}$ test were used in the study.Scheffe, one of the Post-Hoc multiple comparison tests, to determine the source of significant difference in the ANOVA test; Bonferroni multiple comparison test was used to determine the source of significant difference in Kruskal-Wallis $\mathrm{H}$ test.

While there was a significant difference in the individual preparedness perception levels of teachers and school administrators for the epidemic in terms of age, gender, educational status, marital status and monthly income; no significant difference was found in terms of number of children and title variables.In addition, it was determined that the individual preparedness perception levels of teachers and school administrators for the epidemic were at a high level due to the "I agree" level for the overall scale.

The individual preparedness perception levels of teachers and school administrators for the epidemic, in terms of age variable; significant differences in favor of 31-40 age group for the binary groups between in the 21-30 age group and 31-40 age group and in favor of the 41-50 age group in the binary groups between the ages of 21-30 and 41-50 in the overall scale and "perceived benefit" dimension; show that the individual preparedness perception levels for the epidemic are higher in the older teachers and school administrators.

In terms of gender variable; significant results were found in favor of women compared to men in the overall scale and in the "perceived sensitivity" and "perceived seriousness" sub-dimensions.These results show that female teachers and school administrators have higher individual preparedness perception levels for the epidemic than male teachers and school administrators. In terms of education status variable; a significant 
difference was found in the "perceived seriousness" dimension, in favor of those with "undergraduate degree" in the binary groups of "high school graduate" and "undergraduate degree" and in favor of those with "graduate degree" in the binary groups of "college graduate" and "bachelor's degree ".These results show that postgraduate teachers and school administrators have higher perceptions of individual preparedness for the epidemic compared to lower levels of education.In terms of marital status variable; In terms of marital status variable; when the averages were evaluated for the significant differences in the "perceived barriers" and "activators" dimensions and in the overall scale, the results were in favor of the married group; and in the "self-efficacy" dimension, when the averages are evaluated for significant difference, the result was in favor of the single group. These results show that teachers and school administrators who are married have a higher perception of individual preparedness for the epidemic than those who are single.In terms of the number of children variable; no significant difference was observed in the scale and sub-dimensions. This result shows that the perception of individual preparedness for the epidemic did not change according to the number of children of teachers and school administrators.In terms of monthly income status variable; a significant difference in the dimension of "perceived seriousness" was observed in favor of the group with a monthly income of "4,500-5,000 TL" between the group with an income level of "4,500 - 5,000 TL" and the group with a monthly income of "5,500 TL and above".In terms of the title variable; no significant difference was observed in the scale and sub-dimensions.This result shows that the level of individual preparedness perception for the epidemic did not change according to the title variable of teachers and school administrators.It is considered that this research will raise awareness among teachers and school administrators about the preparations of individuals before they contract the disease and the treatment process after the disease, especially in the COVID-19 epidemic, which we are under the influence of "Pandemic"; and alson it is considered that it will also be a source of future research on this subject. 


\section{Kaynakça/References}

Büyüköztürk, Ş. (2010). Sosyal bilimler için veri analizi el kitabı: İstatistik, araştırma deseni. SPSS uygulamaları ve yorum. Ankara: Pegem Akademi.

Büyüköztürk, Ş., Çakmak, E. K., Akgün, Ö. E., Karadeniz, Ş. ve Demirel, F. (2017). Bilimsel araştırma yöntemleri. Ankara: Pegem Akademi.

Can, A. (2017). SPSS ile bilimsel araştırma sürecinde nicel veri analizi. Ankara: Pegem Akademi.

Champion V. (1994) Relationship of age to mammography compliance. Cancer. 74(1), 329-335.

Skinner C. S. (2008). The health belief model. In: Glanz K, Rimer B.K, Viswanath K.V. eds. Health Behavior and Health Education: Theory, Research and Practice. 4th ed. San Francisco, p.46-65.

Ersin F. ve Bahar Z. (2012). Sağlığı geliştirme modellerinin meme kanserini erken teşhis davranışları üzerindeki etkileri: Bir literatür taraması. Dokuz Eylül Üniversitesi Hemşirelik Yüksekokulu Dergisi. 5, 28-38.

Glanz K, Lewis F.M. and Rimers B.K. (Eds.) (2002). Health behavior and health education: Theory, research and practice. San Fransisco, CA: JosseyBass.

Gözüm, S. ve Aydın, I. (2004). Meme kanseri taramalarında Champion'un Sağlık İnanç Modeli Ölçeğinin Türkçe uyarlamalarına ilişkin sonuçlar. Hemşirelikte Araştırma Geliştirme Dergisi, 1, 71-85.

Gözüm, S. ve Çapık, C. (2014). Sağlık davranışlarının geliştirilmesinde bir rehber: Sağlık İnanç Modeli. Dokuz Eylül Üniversitesi Hemşirelik Yüksekokulu Elektronik Dergisi, 7(3), 230-237.

Hochbaum GM. (1958). Public participation in medical screening programs: a socio-psyhologicial study. Washington, DC: US Dept. Health, Educ. Welf.

İnal, E. (2015). Acil durumlaralafetlere bireysel hazırlı̆̆g değerlendirmek için Să̆lık Inanç Modeli'ne dayalı ölçek geliştirme. (Yayımlanmamış Doktora Tezi). Hacettepe Üniversitesi Halk Sağlığı Enstitüsü, Ankara.

Kahraman G, Baş, T. ve Akbolat, M. (2015). Obeziteye yönelik tutum ve inançların geliştirilmesinde sağlık programlarının etkisi. Acıbadem Üniversitesi Să̆lık Bilimleri Dergisi, 6(2), 89-98.

Karakaya, İ. (2012). Bilimsel araştırma yöntemleri. A. Tanrıöğen (Edt.) Bilimsel araştırma yöntemleri. Ankara: Anı Yayıncılık.

Öz, F. (2004). Sağlık alanında temel kavramlar. Ankara: İmaj İç ve Diş Tic. A.Ş. 
Öztek, A. Z., Üner, S. ve Eren, N. (2012). Halk sağhı̆̆ı kavramı ve gelişmesi. Halk sağliğı temel bilgiler. Ankara: Hacettepe Üniversitesi Yayınları.

Özvarış, B. Ş. (2011). Să̆ğğı geliştirme ve să̆lık ĕ̆itimi. Ankara: Hacettepe Yayınları.

Peker, A.T. ve Zengin, S. (2019). Sağlık hizmetleri meslek yüksekokulu öğrencilerinin spor sağlık inanç düzeylerinin değerlendirilmesi. Ekev Akademi Dergisi, 77, 45-56.

Rosenstock, L.M. (1974). Historicalorigins of the health belief model. Health Education Monographs, 2, 328-335.

Türkiye Halk Sağlığı Kurumu Kanser Daire Başkanlığı. (Erişim Tarihi: 20.11.2020) https://hsgm.saglik.gov.tr/tr/kanser-taramaları.

Ünsal A. (2017). Hemşireliğin dört temel kavramı: İnsan, Çevre, sağlık \& hastalık, hemşirelik. Ahi Evran Üniversitesi Sağlık Bilimleri Dergisi, 1(1), 11-28.

World Health Organization (WHO) (1946). International Health Conference, New York. Erişim Tarihi: 20.11.2020. http://www.who.int/about/definition/en/print.html.

World Health Organization. (1984). WHO definition of Health. Retrieved in (Erişim Tarihi: 20.11.2020) www.who.int/about/definition/en/print.html

\section{Kaynakça Bilgisi / Citation Information}

Kaya, A., Moçoşoğlu, B. ve Sevim, H. İ. (2021). Sağlık İnanç Modeli' ne dayalı olarak öğretmenler ve okul yöneticilerinin salgına yönelik bireysel hazırlık algılarının incelenmesi. OPUS-Uluslararası Toplum Araştırmaları Dergisi, 18(40), 2345-2374. DOI:10.26466/opus.868717. 